MaPan : Jurnal Matematika dan Pembelajaran

p-ISSN: 2354-6883 ; e-ISSN: 2581-172X

Volume 4, Nomor 1, Juni 2016

\title{
KEEFEKTIFAN MODEL KOLB-KNISLEY DITINJAU DARI PRESTASI BELAJAR, KEMAMPUAN PENALARAN, DAN SELF-ESTEEM SISWA
}

\author{
Andi Kusumayanti1), Dhoriva Urwatul Wutsqa ${ }^{2)}$ \\ 1Jurusan Pendidikan Matematika, FTK UIN Alauddin Makassar \\ ${ }^{1}$ Kampus II: Jalan H. M. Yasin Limpo Nomor 36 Samata-Gowa \\ 2Universitas Negeri Yogyakarta \\ 2Kampus: Jalan Colombo No.1, Caturtunggal, Yogyakarta, 55281 \\ E-mail: andikusumayanti@ymail.com ${ }^{1)}$, dhoriva@yahoo.com ${ }^{2)}$
}

\begin{abstract}
Abstrak
Penelitian ini bertujuan untuk mendeskripsikan keefektifan (MPMK-K) Model Pembelajaran Matematika Kolb-Knisley ditinjau dari prestasi belajar, kemampuan penalaran matematis, dan self-esteem siswa;pembelajaran yang lebih efektif antara MPMK-K dengan pembelajaran konvensional ditinjau dari prestasi belajar, kemampuan penalaran matematis, dan self-esteem siswa. Penelitian ini adalah penelitian eksperimen semu dengan desain kelompok pretest-posttest. Penelitian ini menggunakan satu kelompok eksperimen (MPMK-K) dan satu kelompok kontrol (pembelajaran konvensional).Populasi penelitian ini adalah seluruh siswa kelas VIII SMP Muhammadiyah 4 Yogyakartasebanyak 4 kelas. Sampel penelitian sebanyakdua kelas VIII yang dipilih secara acak.Data hasil penelitian dianalisis dengan menggunakan one sample t-test untuk mengetahui keefektifan MPMK-K dan konvensional. Setelah itu dilanjut dengan Multivariate Analysis of Variance (MANOVA)untuk mengetahui perbedaan keefektifan antara kelas eksperimen dan kelas kontrol. Untuk membandingkan MPMKKdengan pembelajaran konvensional digunakan uji univariat independent sample t-test. Hasil penelitian menunjukkan bahwa: MPMK-K dan pembelajaran konvensional efektif terhadap pembelajaran matematika ditinjau dari prestasi belajar, kemampuan penalaran matematis, dan selfesteem siswa; MPMK-K lebih efektif dari pembelajaran konvensional ditinjau dari prestasi belajar, kemampuan penalaran matematis, dan selfesteem siswa.
\end{abstract}

Kata Kunci: MPMK-K, Prestasi Belajar, Kemampuan Penalaran Matematis, Self-Esteem Siswa

$\mathrm{P}$ endidikan merupakan kebutuhan yang tidak bisa lepas dalam kehidupan manusia karena memiliki banyak peranan dalam menggapai cita-cita setiap insan manusia begitupun dengan perkembangan setiap bangsa. Pendidikan juga bisa diartikan sebagai proses perkembangan individu untuk meneruskan kehidupannya. Salah satu pendidikan yang harus diajarkan kepada peserta didik adalah pembelajaran 
matematika. Penguasaan matematika yang diperlukan secara umum termuat dalam tujuan pembelajaran matematika. Berdasarkan PERMENDIKNAS No. 22 Tahun 2006, mata pelajaran matematika bertujuan agar peserta didik memiliki kemampuan berikut: 1) memahami konsep matematika; 2) menggunakan penalaran pada pola dan sifat; 3) memecahkan masalah yang meliputi kemampuan memahami masalah; 4) mengomunikasikan gagasan dengan simbol, tabel, diagram, atau media lain; 5) memiliki sikap menghargai kegunaan matematika dalam kehidupan.

Menurut Russeffendi Suherman et al, (2003 :16) matematika terbentuk sebagai hasil pemikiran manusia yang berhubungan dengan ide, proses, dan penalaran. Sedangkan menurut Reys et a, (2009 : 2) matematika adalah studi tentang pola dan hubungan, cara berpikir dengan strategi organisasi, analisis dan sintesis, seni, bahasa, dan alat untuk memecahkan masalah-masalah abstrak dan praktis. Sementara itu Suherman et al, (200: 16) mengatakan bahwa matematika terbentuk dari pengalaman manusia dalam dunianya secara empiris lalu kemudian pengalaman itu diproses dalam dunia rasio, diolah secara analisis dengan penalaran di dalam struktur kognitif sehingga sampai terbentuk konsep-konsep matematika supaya konsep-konsep matematika yang terbentuk itu mudah dipahami oleh orang lain dan dapat dimanipulasi secara tepat, maka digunakan bahasa matematika atau notasi matematika yang bernilai global. Berdasarkan penjelasan di atas mengenai matematika dan hubungannya dengan penalaran dapat disimpulkan bahwa penguasaan materi matematika oleh siswa menjadi suatu keharusan yang tidak bisa ditawar lagi di dalam penataan nalar dan pengambilan keputusan dalam era persaingan yang semakin kompetitif ini.

Berdasarkan penjelasan di atas menyatakan bahwa salah satu tujuan pembelajaran matematika yang perlu untuk dikembangkan dan ditingkatkan adalah kemampuan penalaran matematis. Kemampuan penalaran matematis merupakan salah satu aspek yang sangat penting dan sangat berpengaruh terhadap prestasi belajar siswa.

Meskipun kemampuan penalaran sangat penting karena berpengaruh terhadap prestasi belajar, pada kenyataannya kedua aspek tersebut belum memperoleh hasil yang baik bagi siswa Indonesia. Hal tersebut dapat dilihat pada hasil TIMSS 2011 yang menjelaskan bahwa perkembangan domain kognitif khususnya kemampuan penalaran (reasoning) Indonesia menurun dari tahun 2007 ke tahun 2011, pada tahun 2011 skor rata-rata Indonesia $388(3,8)$ 
sedangkan tahun 2007 skor rata-ratanya $394(3,5)$ sehingga perbedaan skor rata-rata Indonesia antara tahun 2007 dan 2011 adalah -7 (5,2).

Selain itu berdasarkan data BSNP 2012/2013 mengatakan bahwa berdasarkan data laporan hasil sekolah dapat diketahui bahwa SMP Muhammadiyah 4 berada pada klasifikasi D dengan rata-rata nilai matematika 5,35, nilai ujian terendah 1,75, dan nilai ujian tertinggi 10,00 dengan standar deviasi 1,99. Hal ini berarti bahwa prestasi belajar matematika siswa SMP Muhammadiyah 4 Yogyakarta masih tergolong rendah.

Adanya fakta hasil TIMSS 2011 dan 2007 pada domain proses kognitif bahwa kemampuan penalaran siswa yang masih lemah dan data dari BSNPmenjadi indikasi masih rendahnya prestasi belajar dan kemampuan penalaran matematis siswa. Oleh karena itu, hasil TIMSS 2011 dan 2007 dapat dijadikan dasar bahwa kemampuan penalaran matematis siswa kelas VIII memerlukan perhatian khusus.

Untuk melihat penyebab rendahnya prestasi belajar, kemampuan penalaran matematis siswa yang perlu diperhatikan adalah proses pelaksanaan pembelajaran karena pada saat proses pembelajaranlah siswa mampu memahami materi yang telah diberikan oleh guru dan mengembangkan berbagai kemampuan yang dimilikinya. Seperti yang diungkapkan oleh Putra (2012: 8) dalam penelitiannya yang mengatakan bahwa kemampuan penalaran dan komunikasi siswa di Indonesia masih rendah, hal ini diindikasikan dari interaksi siswa dengan gurunya serta siswa dengan proses pembelajarannya juga tidak berjalan dengan baik sehingga menyebabkan proses pembelajaran yang tidak berlangsung efektif. Hal ini membuat sikap siswa terhadap proses pembelajaran matematika cenderung pasif dan cenderung negatif karena disetiap pertemuan siswa sudah mempunyai persepsi awal yang membosankan dan kurang menarik. Selain membosankan, sulitnya belajar matematika ternyata tidak efisien dengan model pembelajaran yang digunakan sehingga siswa tidak berhasil saat belajar matematika.

Rendahnya prestasi belajar dan kemampuan penalaran tidak terlepas dari peran guru dalam mengelola pembelajaran. Pada proses pembelajaran guru cenderung memindahkan pengetahuan yang dimiliki ke pikiran siswa, pembelajaran bersifat mekanistik, siswa kurang terlibat aktif dalam proses pembelajaran. Hal ini mengakibatkan sempitnya kesempatan siswa untuk mengembangkan semua potensi yang dimilikinya. Pembelajaran akhirnya hanya berpusat pada guru (teacher oriented), siswa jadi pasif karena hanya 
mendengarkan pelajaran yang diberikan oleh guru. Aktivitas pembelajaran seperti ini mengakibatkan terjadinya penghafalan konsep dan prosedur, sehingga aktivitas penalaran kurang distimulus oleh guru.

Selain aspek kognitif, aspek lain yang juga berkontribusi besar mempengaruhi prestasi belajar matematika adalah aspek afektif yakni selfesteem. Hal ini sejalan dengan pernyataan Muijs \& Reynolds (2008) yang mengatakan bahwa self-esteem yang rendah memiliki efek yang merugikan terhadap prestasi belajar siswa. Self-esteem sangat penting untuk dimiliki siswa karena ketika dalam diri siswa telah terbentuk self-esteem yang tinggi maka siswa akan selalu optimis serta tidak mudah putus asa dalam meghadapai masalah- masalah belajarnya. Sebaliknya, siswa yang memiliki self-esteem matematis yang rendah akan memandang dirinya lemah, tidak mempunyai gairah hidup, tidak berdaya, dan tidak mampu berbuat apa-apa dalam menghadapi berbagai masalah matematis.

Namun pada kenyataannya banyak diantara para pendidik, khususnya dibidang matematika belum sadar bahkan belum mengetahui fakta bahwa salah satu aspek psikologi yang dinamakan self-esteem ini dapat mempengaruhi pencapaian prestasi seorang siswa. Berdasarkan hasil penelitian yang dilakukan oleh Pujiastuti (2013: 9) menyimpulkan bahwa selfesteem matematis siswa SMP tergolong masih rendah. Studi yang melibatkan 125 siswa tersebut mengungkapkan bahwa rerata skor self-esteem matematis yang diperoleh siswa mencapai 43 dan skor tertingginya hanya mencapai 54 , sementara skor maksimal idealnya adalah 80 . Bila dipersentasekan rata-rata skor self-esteem matematis siswa tersebut hanya mencapai 53,75\% dari skor maksimal ideal dan masih tergolong rendah. Selain itu, berdasarkan observasi yang telah dilakukan oleh peneliti di SMP Muhammadiyah 4 Yogyakarta dapat diketahui bahwa self-esteem matematika siswa tergolong rendah, hal ini sesuai dengan pernyataan salah satu gurunya yang mengatakan bahwa hampir semua siswa belum mampu meyakini kemampuan yang dimilikinya dan kurang aktif mengekspresikan diri.

Untuk menjawab semua permasalahan yang telah dijelaskan dibutuhkan solusi yang tepat untuk mempengaruhi prestasi belajar, kemampuan penalaran matematis siswa dan salah satu cara mengatasi permasalahan siswa di atas adalah dengan menggunakan model pembelajaran yang sesuai dengan kebutuhan siswa sehingga mampu mempengaruhi prestasi belajar siswa agar pembelajarannya semakin bermakna, siswa lebih aktif dan mampu mengekspolorasi kemampuan-kemampuan yang 
dimilikinya. Dengan kata lain, perlu suatu pembelajaran yang dapat memfasilitasi siswa untuk berperan aktif, menarik dan menantang siswa untuk berpikir sehingga berpengaruh pada kemampuan penalaran matematis siswa dan prestasi belajar matematikanya. Hal ini sesuai dengan pandangan pembelajaran dalam kurikulum 2013 yang mengarahkan kegiatan pembelajaran untuk memberdayakan semua potensi yang dimiliki peserta didik.

Salah satu alternatif model pembelajaran yang berpotensi memenuhi standar pembelajaran matematika dalam kurikulum 2013 dan diperkirakan dapat mempengaruhi prestasi belajar dan kemampuan penalaran matematis siswa adalah model pembelajaran matematika Kolb-Knisley. MPMK-K merupakan penerapan teori kolb learning cycle dalam pembelajaran matematika yang mengarahkan siswa untuk belajar dimulai dari hal yang konkret yakni dengan merumuskan konsep baru berdasarkan konsep yang telah diketahuinya sampai ke hal yang abstrak yakni menyelesaikan masalah berdasarkan konsep yang telah dibentuk.Menurut Knisley (2003: 12) Kolb's learning styles can be interpreted as mathematical learning styles. I have interpreted Kolb's other three learning styles in a mathematical context:

a. Allegorizers: These students consider new ideas to be reformulations of known ideas. They address problems by attempting to apply known techniques in an adhoc fashion.

b. Integrators: These students rely heavily on comparisons of new ideas to known ideas. They address problems by relying on their "common sense" insights - i.e., by comparing the problem toproblems they can solve.

c. Analyzers: These students desire logical explanations and algorithms. They solve problems with a logical, step-by-step progression that begins with the initial assumptions and concludes with the solution.

d. Synthesizers: These students see concepts as tools for constructing new ideas and approaches. They solve problems by developing individual strategies and new allegories.

Menurut Mulyana (2009:44), model pembelajaran Knisley memiliki keunggulan diantaranya meningkatkan semangat siswa untuk berpikir aktif, membantu suasana belajar yang kondusif karena siswa bersandar pada penemuan individu, memunculkan kegembiraan dalam proses belajar mengajar karena siswa dinamis dan terbuka dari berbagai arah. Selanjutnya Mulyana mengatakan seluruh tahapan pada MPMK-K menyiratkan pembelajaran matematika didasarkan atas pengetahuan yang terstruktur 
dengan baik, mengaitkan konsep-konsep baru dengan pengetahuan dan pengalaman siswa sebelumnya.Menurut Knisley, terdapat empat tahapan pembelajaran yang berbeda untuk memperoleh suatu konsep baru, yaitu allegorisasi, integrasi, analisis, dan sintesis.

a. Allegorisasi: suatu konsep baru dirumuskan secara figuratif dikaitkan dengan konsep-konsep yang telah diketahui dengan baik.

b. Integrasi: perbandingan, pengukuran, dan eksplorasi digunakan untuk membedakan konsep baru dari konsep yang telah diketahui.

c. Analisis: konsep baru menjadi bagian dari pengetahuan yang telah ada. Pada tahap ini, pebelajar dapat menghubungkan konsep baru dengan konsep yang telah diketahuinya, tetapi mereka kekurangan informasi yang diperlukan untuk membuat ciri yang khas dari konsep itu.

d. Sintesis: konsep baru memperoleh identitas yang unik dan menjadi suatu alat untuk mengembangkan strategi dan allegorisasi berikutnya. Pada tahapan ini, pebelajar telah menguasai konsep dan dapat menggunakannya untuk memecahkan masalah, mengembangkan strategi, dan menciptakan allegoris.

Pembelajaran ini mengawali langkahnya dengan mengajak siswa untuk mengingat kembali konsep yang telah dipelajari sebelumnya dan berkaitan dengan konsep yang akan mereka pelajari yang disebut dengan tahap konkret-reflektif, selanjutnya tahap konkret-aktif siswa diberikan soal-soal penerapan konsep baru secara sederhana dengan tugas eksplorasi sifa-sifat konsep baru tersebut (Mulyana, 2009: 142) , siswa pada tahap ini akan membedakan konsep baru dengan konsep lama yang telah mereka ketahui dengan berbagai hasil eksplorasinya. Pada tahap abstrak-reflektif siswa akan menghubungkan konsep lama dan konsep baru yang telah mereka ketahui dengan merumuskan satu solusi yang nantinya akan dijadikan sebagai alasan logis yang dapat menjelaskan dugaan dari kedua konsep tersebut. Tahap abstrak-aktif, siswa akan menggunakan hasil rumusan yang telah mereka buat yang diterapkan pada latihan. Berdasarkan penjelasan tersebut MPMK-K memberikan ruang kepada siswa untuk dapat mengeksplor semua ide dan memahami suatu konsep dan keterkaitannya dengan konsep lainnya.

McCarthy (Knisley, 2003:15) menganjurkan pembelajaran di dalam kelas secara ideal melalui setiap tahap dari empat proses pembelajaran itu. Sementara peranan guru yang didasarkan atas siklus belajar Kolb terdapat paling sedikit empat peranan yang berbeda dari guru matematika. Menurut Knisley (2003: 15). 
"Likewise, the four stages of mathematical learning described above imply at least four different roles for the teacher of mathematics, (1) Allegorization: Teacher is a storyteller, (2) Integration: Teacher is a guide and motivator, (3) Analysis: Teacher is a source of information, (4) Synthesis: Teacher is a coach".

Artinya adalah pada proses tahap kongkrit-reflektif guru berperan sebagai storyteller (pencerita), pada tahap kongkrit-aktif guru berperan sebagai pembimbing dan pemberi motivasi, pada tahap abstrak-reflektif guru berperan sebagai sumber informasi, dan pada tahap abstrak-aktif guru berperan sebagai coach (pelatih). Pada tahap kongkrit-reflektif dan tahap abstrak-reflektif guru relatif lebih aktif sebagai pemimpin, sedangkan pada tahap kongkrit-aktif dan abstrak-aktif siswa lebih aktif melakukan eksplorasi dan ekspresi kreatif sementara guru berperan sebagai mentor, pengarah, dan motivator. Siklus MPMK-K sangat menarik, karena tingkat keaktifan siswa dan guru saling bergantian, tahap pertama dan tahap ketiga guru lebih aktif dari pada siswa, sedangkan pada tahap kedua dan keempat siswa lebih aktif dari pada guru (Mulyana, 2009:36). Penelitian ini juga bertujuan untuk mendeskripsikan keefektifan (MPMK-K) Model Pembelajaran Matematika Kolb-Knisley ditinjau dari prestasi belajar, kemampuan penalaran matematis, dan self-esteem siswa serta untuk mengetauhi pembelajaran yang lebih efektif antara MPMK-K dengan pembelajaran konvensional ditinjau dari prestasi belajar, kemampuan penalaran matematis, dan self-esteem siswa

\section{METODE PENELITIAN}

Subjek penelitian ini adalah siswa kelas VIII A dan VIII B SMP Muhammadiyah 4 Yogyakarta Tahun Ajaran 2014/2015 yang terdiri dari 30 siswa dan 29 siswa. Penelitian ini merupakan eksperimen semu dengan desain penelitian pretest-posttest nonequivalen control group design. Pada desain ini terdapat dua kelompok yaitu kelompok eksperimen yang menerapkan MPMK-K dan kelompok kontrol yang menerapkan pembelajaran konvensional. Adapun teknik pengumpulan data yang digunakan dalam penelitian ini adalah mengumpulkan data sebelum diberikan perlakuan yaitu dengan memberikan pretest prestasi belajar, kemampuan penalaran matematis, dan self-esteem siswa; melakukan tindakan penelitian dengan memberikan perlakuan MPMK-K pada kelas eksperimen; dan mengumpulkan data setelah diberikan perlakuan pada kelas eksperimen dan kontrol dengan memberikan posttestprestasi belajar, kemampuan penalaran matematis, dan self-esteem siswa. 
Teknik analisis data yang digunakan dalam penelitian ini adalah analisis deskriptif dan inferensial.Analisis deskriptif untuk mendeskripsikan keadaan sebelum dan sesudah diberikan perlakuan pada kedua kelas ditinjau dari masing-masing variabel terikatnya. Analisis inferensial dilakukan untuk mengambil kesimpulan berdasarkan data yang telah diperoleh selama proses penelitian berlangsung.Analisis inferensial ini terdiri dari uji keefektifan dan uji komparasi pembelajaran matematika.

\section{HASIL PENELITIAN DAN PEMBAHASAN}

Hasil penelitian ini terdiri dari hasil uji keefektifan dan uji komparasi keefektifan antara kelompok kelompok eksperimen yang menggunakan MPMK-K dan kelompok kontrol yang menggunakan pembelajaran konvensional.Hasil uji keefektifan dengan menggunakanone sample t-testakan disajikan pada tabel 1 sebagai berikut

Tabel 1. Hasil Uji Keefektifan MPMK-K

\begin{tabular}{ccc}
\hline Aspek & $\boldsymbol{T}$ & Sig. \\
\hline PBM & 12,55 & 0,000 \\
KPM & 9,94 & 0,000 \\
SE & 11,93 & 0,000 \\
\hline
\end{tabular}

Berdasarkan hasil analisis perhitungan dengan bantuan SPSS for windows 20.00 dapat diketahui bahwa diperoleh nilai $t=12,55$ untuk aspek prestasi belajar matematika, $\mathrm{t}=9,94$ untuk aspek kemampuan penalaran matematis, dan $t=11,93$ untuk aspek self-esteem siswa terhadap pembelajaran matematika dengan keseluruahn nilai signifikansi sebesar 0,000.Jadi dapat disimpulkan bahwa model pembelajaran matematika Kolb-Knisley efektif ditinjau dari prestasi belajar, kemampuan penalaran matematis dan self-esteem siswa terhadap pembelajaran matematika karena nilai signifikansinya kurang dari 0,05 yang berarti bahwa $\mathrm{H}_{0}$ ditolak. Setelah melakukan uji keefektifan, maka dilanjutkan dengan menguji perbedaan keefektifan antara MPMK-K dengan pembelajaran konvensional menggunakan uji multivariat $T^{2}$ Hotelling dengan bantuan SPSS 20,0 for Windows. Hasil perhitungan tersebut menunjukkan bahwa taraf signifikansi yang diperoleh 0,001<0,05.Ini menunjukkan bahwaterdapat perbedaan keefektifan antara kelas eksperimen dengan kelas kontrol ditinjau dari prestasi belajar, kemampuan penalaran matemamatis dan self-esteem siswa terhadap pembelajaran matematika. Karena 
berdasarkan hasil perhitungan tersebut menyatakan terdapat perbedaan keefektifan, maka untuk dapat menyimpulkan mana yang lebih efektif terlebih dahulu akan di uji kembali dengan menggunakan uji independent sample t-test.

Tabel 2. Hasil Independet Sample t-test

\begin{tabular}{cccc}
\hline \multirow{2}{*}{ Aspek } & \multicolumn{3}{c}{ t-test } \\
\cline { 2 - 4 } & T & Df & Sig (1-tailed) \\
\hline PBM & 2,977 & 55,38 & 0,002 \\
KPM & 2,946 & 54,45 & 0,0025 \\
SE & 2,653 & 55,62 & 0,005 \\
\hline
\end{tabular}

Berdasarkan hasil perhitungan pada tabel 2 terlihat bahwa nilai signifikansi dari masing-masing variabel terikatnya adalah lebih kecil 0,01.Dengan demikian dapat disimpulkan bahwa pembelajaran matematika dengan MPMK-K lebih efektif daripada pembelajaran konvensional ditinjau dari prestasi belajar, kemampuan penalaran matematis dan self-esteem siswa terhadap pembelajaran matematika.Hal ini sesuai dengan hasil analisis deskriptif yang menunjukkan bahwa rata-rata pada kelas eksperimen lebih besar dari pada kelas kontrol, sehingga rata-rata tersebut memberikan kontribusi maksimal pada kelas eksperimen.

Berdasarkan hasil analisis despritif juga menunjukkan bahwa pembelajaran matematika dengan MPMK-K berdampak positif terhadap prestasi belajar, kemampuan penalaran matematis dan self-esteem siswa terhadap pembelajaran matematika.Hal ini terlihat dari kondisi awal siswa sebelum dan sesudah diberikan perlakuan.Pada kondisi awal di kelas eksperimen tidak ada satupun siswa yang mencapai ketuntasan untuk prestasi belajar dan kemampuan pemecahan masalah.Namun untuk self-esteem baik pada kelas kontrol ataupun kelas eksperimen sudah mencapai tuntas hanya saja belum ada siswa yang mencapai kriteria sangat tinggi dan masih banyak siswa yang berada pada kriteria sedang Sehingga perlakuan tetap harus dilakukan untuk melihat seberapa besar kemajuan yang dibuat oleh suatu model.Berikut adalah hasil analisis deskriptif dari kedua kelas. 
Tabel 3. Rerata Kelas Eksperimen dan Kelas Kontrol

\begin{tabular}{ccccc}
\hline \multirow{2}{*}{ Deskripsi } & \multicolumn{2}{c}{ MPMK-K } & \multicolumn{2}{c}{ Konvensional } \\
\cline { 2 - 5 } & Pre & Post & Pre & Post \\
\hline PBM & 41,25 & 87,28 & 33,75 & 83,28 \\
KPM & 38,14 & 85,38 & 33,40 & 81,07 \\
SE & 121,60 & 168,34 & 119,55 & 157,97 \\
\hline
\end{tabular}

Berdasarkan hasil uji hipotesis yang telah dijelaskan dapat diketahui bahwa nilai uji one sample t-test untuk pembelajaran model Kolb-Knisley efektif ditinjau dari prestasi belajar matematika. Faktor yang menyebabakan MPMK$\mathrm{K}$ efektif karena melalui MPMK konsep dijelaskan secara secara figuratif dalam konteks yang familiar dengan pengetahuan yang telah dimiliki siswa (Mulyana, 2009:10).Selain sejalan dengan kajian teori, hasil uji hipotesis penelitian ini pun sejalan hasil penelitian yang dilakukan oleh Abidin et al (2011:149) mengatakan bahwa gaya belajar dapat mempengaruhi prestasi belajar setiap siswa. Sementara itu menurutteori Hosnan (2014, p.381) yang menyatakan bahwa salah satu keuntungan dari pembelajaran Kolb atau experiential learning adalah dapat meningkatkan semangat dan gairah pembelajar, membantu terciptanya suasana belajar yang kondusif, serta menolong pembelajar untuk dapat melihat dalam perspektif yang berbeda.

Berdasarkan hasil analisis deskriptif, terlihat pula bahwarerata siswa sebelum dan sesudah diberikan perlakuan mengalami peningkatan sehingga MPMK-K dapat membantu siswa untuk meningkatkan kemampuan penalaran matematisnya.Hal ini sejalan dengan penelitian yang dilakukan oleh Kablan \& Kaya (2013:107) yang mengatakan bahwa dengan gaya belajar asimilator dan konverger siswa dapat mengembangkan pemahaman konseptualnya serta kemampuan penalarannya. Hal ini juga sejalan dengan penelitian yang telah dilakukan oleh Mulyana (2009:10) yang mengatakan bahwa model pembelajaran matematika Kolb-Knisley berpengaruh baik terhadap adaptive reasoning, karena MPMK-K mengembangkan penalaran siswa dalam semua tahapan pembelajaran. Hal ini dikarenakan sebagian besar siswa masih kesulitan dalam melakukan operasi hitung bilangan bulat.

Berdasarkan hasil uji hipotesis yang telah dijelaskan dapat diketahui bahwa nilai uji one sample t-test untuk pembelajaran model Kolb-Knisley efektif ditinjau dari self-esteem siswa. Hal ini sejalan dengan kajian teori yang menyatakan bahwa MPMK-K diharapkan efektif ditinjau dari aspek kemampuan penalaran matematis self-esteem siswa siswa. Hal ini disebabkan 
karena pada tahap kongkrit-aktif guru berperan sebagai motivator atau dengan kata lain pada tahap ini guru mempunyai kesempatan untuk memotivasi siswa.Dengan demikian dapat disimpulkan bahwa salah satu faktor yang mempengaruhi prestasi belajar matematika siswa adalah sikap terhadap matematika, dan salah satu faktor yang mempengaruhi sikap siswa terhadap matematika adalah gaya belajar sehingga guru dituntut untuk mengetahui gaya belajar tertentu dari siswanya

Berdasarkan hasil pengamatan guru selama proses penelitian, terdapat beberapa masalah yang dihadapi oleh siswa diantaranya adalah siswa masih kesulitan dalam memodelkan permasalahan dunia nyata ke dalam bentuk kalimat matematika. Selain itu siswa juga mengalami kesulitan ketika menentukan strategi atau cara apa yang akan digunakan untuk menyelesaikan masalah sehingga sebagian siswa memilih untuk menggunakan cara yang sesuai dengan tingkat berpikir mereka apabila diberikan suatu permasalahan dalam bentuk soal latihan.

Hasil analisis data pretest dengan menggunakan Manova menunjukkan bahwa tidak ada perbedaan kemampuan awal siswa pada materi SPLDV antara kelas eksperimen dan kelas kontrol ditinjau dari prestasi belajar, kemampuan penalaran matematis, dan self-esteem siswa. Ini berarti sebelum diberikan perlakuan pada kelas eksperimen ataupun kelas kontrol ditinjau dari ketiga variabel terikat tersebut tidak berbeda kemampuan awalnya. Sehingga kedua kelas berada pada tingkatan yang sama sebelum perlakuan. Namun setelah diberikan perlakuan, Nampak perbedaan antara kedua kelas ditinjau dari masing-masing variabel terikatnya.

Hasil analisis menunjukkan bahwa terdapat perbedaaan keefektifan antara kelas eksperimen dan kelas kontrol ditinjau dari prestasi belajar, kemampuan penalaran matematis, dan self-esteem siswa.Dikarenakan terdapat perbedaan keefektifan antara kedua kelompok, maka dilakukan uji univariat independent sample t-test untuk mengetahui rerata variabel kelompok mana yang memberikan kontribusi maksimal terhadap perbedaan keefektifan antara kedua kelompok.Adapun hasil uji lanjut yang telah dilakukan dengan uji independent sample t-test dapat dilihat pada tabel 4 berikut ini. 
Tabel 4. Hasil Independent Sample t-test

\begin{tabular}{cccc}
\hline \multirow{2}{*}{ Aspek } & \multicolumn{3}{c}{ t-test } \\
\cline { 2 - 4 } & $\mathbf{T}$ & Df & Sig (1-tailed) \\
PBM & 2,977 & 55,38 & 0,002 \\
KPM & 2,946 & 54,45 & 0,0025 \\
SE & 2,653 & 55,62 & 0,005 \\
\hline
\end{tabular}

Berdasarkan hasil analisis tersebut terlihat bahwa taraf signifikansi dari ketiga variabel terikatnya kurang dari 0,017. Hal inimenunjukkan bahwa pembelajaran matematika dengan MPMK-K lebih efektif daripada pembelajaran konvensional ditinjau dari prestasi belajar, kemampuan penalaran matematis, dan self-esteem siswa. Hasil ini didukung pula oleh hasil analisis deskriptif yang menunjukkan bahwa rerata kelompok eksperimen lebih tinggi dari kelompok kontrol ditinjau dari prestasi belajar, kemampuan penalaran matematis, dan self-esteem siswa.

\section{SIMPULAN}

MPMK-K efektif ditinjau dari prestasi belajar, kemampuan penalaran matematis, dan self-esteem siswa. Selain itu, terdapat perbedaan keefektifan antara kelas eksperimen dan kelas kontrol sehingga menyebabkan pembelajaran matematika dengan MPMK-K lebih efektif dari pembelajaran konvensional ditinjau dari prestasi belajar, kemampuan penalaran matematis, dan self-esteem siswa.

\section{DAFTAR PUSTAKA}

Abidin, M. J. Z., Rezzae, A. A., Abdullah, H. N., \& Singh, K. K. B. (2011). Learning styles and overall academic achievement in a specific educational system. International journal of humanities and social science. Hlm. 143-152.

Dadan, D. (2009). Meningkatkan kemampuan penalaran dan pemahaman siswa sltp melalui pendekatan pembelajaran open-ended. Bandung: Universitas Pendidikan Indonesia.

Dwi, H. (2013). Penerapan model SSCS dengan pendekatan problem posing untuk meningkatkan kemampuan penalaran dan komunikasi matematis siswa SMP. Tesis. Bandung: Universitas Pendidikan Indonesia. 
Eidelweis,D. J. (2013). Model pembelajaran experential kolb untuk meningkatkan pemahaman konsep dan kemampuan menjelaskan fenomena fisis SMA kelas X pada konsep alat optik. Tesis. Tidak diterbitkan. Bandung: Universitas Pendidikan Indonesia.

Hosnan, M. (2014) . Pendekatan saintifik dan kontekstual dalam pembelajaran abad 21. Bogor: Ghalia Indonesia.

Huberty, C. J., \& Olejnik, S. (2006). Applied MANOVA and discriminant analysis. New Jersey : John Wiley \& Sons, Inc.

Isna, R. (2013). Penerapan model pembelajaran matematika berbasis multiple intelligences untuk meningkatkan kemampuan pemahaman konsep, penalaran matematis dan self-confidences siswa MTs. Tesis. Tidak diterbitkan. Bandung: Universitas Pendidikan Indonesia.

Johnson, R. A., \& Wichern, D. W. (2007). Applied multivariate statistical analysis. New Jersey: Pearson Prentice-Hall, Inc.

Kablan, Z., \& Kaya, S. (2013). Science achievement in TIMSS cognitive domains based on learning styles. Eurasian Journal of Educational Research, 53, 97114.

Muijs, D., \& Reynolds, D. (2008). Effective teaching (3nd ed). London: SAGE Publication.

Mulyana, E. (2009). Pengaruh model pembelajaran matematika knisley terhadap peningkatan pemahaman dan disposisi matematika siswa sekolah menengah atas program ilmu pengetahuan alam. Disertasi. Tidak diterbitkan. Bandung: Universitas Pendidikan Indonesia.

Nasution, S. (2013). Berbagai pendekatan dalam proses belajar dan mengajar. Jakarta: Bumi Aksara.

NCTM. (2000). Principles and standardas for school. Reston, VA: The National Council of Theacher of Mathematics, Inc.

NRC. (2002). Helping children learn mathematics. Washington, DC: National Academic Press. 
Permendiknas. (2006). Peraturan Menteri Pendidikan Nomor 23 Tahun 2006 tentang standar isi (SI) dan standar kompetensi lulusan pendidikan dasar dan menengah. Jakarta: Depdiknas.

Peker, M. (2009) .Pre-service teachers' teaching anxiety about mathematics and their learning styles. Eurasia journal of mathematics, scienxe $\mathcal{E}$ technology education, 5(4), 335-345.

Pujiastuti, H. (2014). Pembelajaran inquiry co-operation model untuk meningkatkan kemampuan pemecahan masalah, komunikasi, dan self-esteem matematis siswa SMP. Disertasi. Bandung: Universitas Pendidikan Indonesia.

Reys, R., Lindquist, M.M., Lambdin, D.V., \& Smith, N.L. (2009). Helping children learn mathematics $9^{\text {th }}$ ed. Boston: John Wiley \& Sons, Inc

Stevens, J. (2009). Applied multivariate statistics for the social sciences. New York: Routledge.

Suherman, E., et al. (2003). Strategi pembelajaran matematika kontemporer. Bandung: JICA.

TIMSS.(2011). International results in mathematics. Boston: Timss \& PIRLS International Study Center.

TIMSS.(2007). International mathematics report. Boston: Timss \& PIRLS International Study Center. 